\title{
Effects of Verb Argument Structure and the Types of Presentation Modality on Verb Production in Individuals with Aphasia Using a Verb-Final Language
}

\author{
Hyesoo Yoon, Jee Eun Sung \\ Department of Communication Disorders, Ewha Womans University, Seoul, Korea
}

Correspondence: Jee Eun Sung, PhD

Department of Communication Disorders, Ewha

Womans University, 52 Ewhayeodae-gil,

Seodamun-gu, Seoul 03760, Korea

Tel: $+82-2-3277-2208$

Fax: +82-2-3277-2122

E-mail: jeesung@ewha.ac.kr

Received: January 5, 2020

Revised: January 31, 2020

Accepted: February 10, 2020

This work was supported by the National Research Foundation of Korea Grant funded by the Korean Government (NRF-2017S1A2A2038375).

\begin{abstract}
Objectives: The purpose of this study was to evaluate the naming performance of persons with aphasia (PWA) by presentation mode and verb argument structure and to investigate the factors that can predict the severity of aphasia. Methods: The participants of this study were 16 aphasia patients and 16 normal individuals who were matched in age and years of education. Verbs were classified into four categories, one-place unergative, one-place unaccusative, two-place, three-place according to the argument structure, and were presented in static and dynamic modes. The correct responses of the participants were calculated and converted into accuracy (\%). Results: The PWA showed significantly lower performance than the control group on the verb naming task. The control group did not show significant difference in verb naming task by verb argument structure and presentation mode, however PWA showed a significant increase in performance on one-place unaccusative and two-place verbs in both presentation modes. Among the variables by presentation mode and verb argument structure, the most predictive variables for severity of aphasia were one-place unergative and unaccusative verb in static mode which predicted the severity of aphasia at a rate of approximately $57.9 \%$. For the dynamic mode, one-place unaccusative verbs were the most predictive variable for severity of aphasia and it predicted severity of aphasia $80.9 \%$ of the time. Conclusion: These results indicated that PWA had more difficulties in naming verbs than the control group and were affected by presentation mode for verb naming tasks. The severity of aphasia was predicted by computational load of passive structure process from object movement on one-place unaccusative verbs.
\end{abstract}

Keywords: Aphasia, Verb, Argument structure, Presentation modality 실어증(aphasia)은 정상적 언어습득을 거친 후 뇌손상으로 인하 여 언어의 표현 또는 이해 등의 다양한 영역에서 결함을 나타내는 언어장애를 말한다(McNeil \& Pratt, 2001). 실어증 환자는 특히 어 휘 인출(word retrieval)의 어려움이 두드러지게 나타난다(Berndt, Mitchum, Haendiges, \& Sandson, 1997; Zingeser \& Berndt, 1990). 이로 인해 이름대기 장애가 나타나며 의미 또는 음소착어, 대치, 에 둘러 말하기, 문법 오류 등의 표면적 문제가 나타나게 된다(Dorze \& Nespoulous, 1989; Raymer, Kohen, \& Saffell, 2006). 실어증 환자
의 어휘 인출 손상을 품사에 따라 비교해 보면 명사보다 동사에서 결함이 두드러지게 나타난다(Hillis \& Caramazza, 1991; Jonkers \& Bastiaanse, 1998; Kim \& Thompson, 2000; Luzzatti et al., 2002; Mätzig, Druks, Masterson, \& Vigliocco, 2009; Zingeser \& Berndt, 1990). 실어증 환자들이 명사에 비해 동사에서 어려움을 보이는 이 유는 동사는 명사에 비해 추상적이고 다양한 의미로 사용되는 경 우가 많아 의미론적 처리가 요구되며, 시제 변화, 주어 일치와 같은 형태론적 처리가 필요하고, 동사에 따른 적절한 논항의 산출과 같 
은 구문론적 처리가 이루어져야 하기 때문이다(Bird, Howard, \& Franklin, 2003; Druks, 2002; Kim \& Thompson, 2000). 그러나 Bates, Chen, Tzeng, Li 그리고 Opie (1991)는 명사에 비해 동사 산 출이 더 손상된 브로카 실어증 환자와 달리 베르니케 실어증 환자 는 동사보다 명사에서 어휘 산출의 결함이 두드러진다고 보고하였 으나, Hyun, Kim, Shin 그리고 Seo (2003)는 베르니케 실어증 환자 는 동사와 명사에서 모두 어휘 산출이 손상되는 것으로 보고하였 다. 즉 실어증 유형에 따른 동사 및 명사산출에 상대적인 결함 여부 는 연구에 따라 차이가 있어, 일반적으로 특정 실어증 유형이 특정 품사의 산출에 더 큰 어려움이 있다고 전제하기에는 연구 결과가 비일관적이다. 또한, McNeil과 Pratt (2001)은 실어증 유형과 병소 부위에 따라 특정 언어증상 출현 여부의 기준을 정의하는 것에 문 제가 있음을 피력하였다. 따라서, 본 연구는 실어증 유형 및 병소 부 위에 따른 분류보다는 실어증 환자들이 전반적으로 동사 산출에 서 보이는 특징을 논항구조와 관련하여 살펴보고자 한다.

논항구조는 신경언어장애군의 동사 산출 수행력을 설명할 수 있 는 동사의 중요한 구조적 측면으로(Sung \& Kwag, 2012) 문장을 구 성하는 서술어가 요구하는 논항과 그 논항들의 의미역 집합을 의 미한다(Nam, 2007). 논항의 수는 동사에 따라 달라지게 된다. 예를 들어, 1 항 동사는 하나의 논항을 필요로 하는 동사로, 비능격 동사 는 '남자가 뛰다.와 같이 행위자(남자) 하나를 필요로 하며, 비대격 동사는 '얼음이 녹다.'와 같이 하나의 대상(얼음)을 주격 논항으로 필요로 하는 동사이다. 2항 동사 '먹다'는 '동생이 밥을 먹다.'와 같 이 행위자(동생)와 대상(밥)이라는 두 개의 논항을 필요로 하며, 3 항 동사인 '주다'는 '아빠가 엄마에게 선물을 주다.'와 같이 행위자 (아빠)와 대상(선물), 수여자(엄마)라는 세 개의 논항을 필요로 한 다. 여러 선행연구에서 실어증 환자의 동사 논항에 따른 산출 능력 의 차이를 연구하였다. Kim과 Thompson (2000)은 미국 실어증 환 자들의 동사 산출 능력이 1 항 동사, 2 항 동사, 3 항 동사 간 유의한 차 이를 보이며, 논항 증가에 따라 결함이 나타났다고 보고하였다. 영 어권뿐만 아니라 이탈리아, 독일, 네덜란드 등 다양한 언어권에서 도 동사 논항의 수가 증가함에 따라 동사 산출에 어려움이 나타났 다는 연구가 보고되었다(De Bleser \& Kauschke, 2003; Jonkers \& Bastiaanse, 1996; Kemmerer \& Tranel, 2000; Kim \& Thompson, 2000; Luzzatti et al., 2002; Thompson, Lange, Schneider, \& Shapiro, 1997).

한편, 국내 실어증 환자들의 동사 산출 능력은 3 항 동사에서 유 의하게 어려움이 나타났으나 1 항 동사와 2 항 동사 간 유의한 차이 는 없었으며, 1 항 비능격 동사에 비해 1항 비대격 동사에서 결함이 나타났다(Kim, 2006; Sung, 2016; Yang, 2016). 영어는 동사에 따라
주어, 목적어, 보어 등의 문장 구성 성분이 명확하게 제시되어야 하 며, 이 중 하나의 성분이 생략되는 경우 불완전한 문장으로 여겨진 다. 반면 한국어는 동사 외의 성분을 생략하여도 문장이 성립되는 특성이 있어, 영어와 비교했을 때 논항 수에 따른 구분이 상대적으 로 명확하지 않아 1 항 동사와 2 항 동사에서 유의한 차이가 나타나 지 않은 것으로 해석된다(Kim, 2006; Sung, 2016; Yang, 2016). 실어 증 환자들이 비능격 동사에 비해 비대격 동사의 산출에 어려움을 보인다는 연구는 대부분의 국내외 선행연구들의 의견이 일치하였 다(Kegl, 1995; Kim, 2006; Sung, 2016; Thompson, 2003; Yang, 2016). 이는 비대격 동사의 경우, 아래의 (a)와 (b)와 같이 심층구조 (deep structure)의 목적격에 해당하는 의미역이 표층구조(surface structure)에서 주격으로 이동하는 통사적 처리 과정에서 논항 이 동이 나타나며, 이로 인해 어순이 도치되고(Kegl, 1995; Sung \& Kwag, 2012) 상태사건이 부각되는 의미적 특성으로 인해 비능격 동사보다 어려움이 증가하게 된다(Yang, 2016).

(a) 한국어

심층구조: $e$ 얼음 녹았다.

표층구조: 얼음(이) 녹았다.

(b) 영어

심층구조: $e$ melted [the ice].

표층구조: the ice melted.

실어증 환자의 동사 산출 능력을 살펴보기 위해 연구자들은 다 양한 자극을 사용해왔다. 실어증 환자 등 다양한 신경언어장애군 의 동사 산출을 알아보기 위해, 애니메이션 또는 비디오를 자극으 로 사용하거나(Kim, 2006; Pashek \& Tompkins, 2002; Sung, 2016) 그림으로 제시하여 왔다(Druks, 2002; Hyun et al., 2003; Zingeser \& Berndt, 1990). 하지만 자극유형에 따른 동사산출의 차이를 비교 한 연구는 제한적이다. Blankestijn-Wilmsen et al. (2017)은 실어증 환자에게 정적 자극으로 사진을 제시하고 동적 자극으로 비디오를 제시하여 고빈도와 저빈도로 구성된 동사 이름대기 과제를 실시하 였을 때, 동적 자극에서 더 높은 수행력을 나타냈다고 보고하였다. Druks와 Shallice (2000)는 실어증 환자에게 정적 자극으로 그림을 제시하고 검사자의 실제 동사 재현을 동적 자극으로 제시하여 20 개의 자동사와 40 개의 타동사로 구성된 동사 이름대기 과제의 수 행을 비교하였으며, 검사자가 동작을 직접 재현하였을 때 높은 수 
행력을 보였다고 하였다. 반면 11 명의 실어증 환자를 대상으로 연구 를 실시한 Berndt et al. (1997)은 정적 자극으로 그림을, 동적 자극 으로 비디오를 제시하여 비다의동사(unambiguous verb)로 구성된 동사 이름대기 과제를 실시하였으며, 자극유형에 따른 유의한 차이 가 나타나지 않았다고 보고하였다.

자극의 제시 유형에 따라 동사 산출이 다르게 나타나는 특성은 실어증 환자뿐만 아니라 다른 신경언어장애군에서도 찾아볼 수 있 다. 전두측두치매(Fronto Temporal Dementia) 환자를 대상으로 한 d'Honincthun와 Pillon (2005)의 연구에서는 사진으로 정적 자 극을 제시하여 명사와 동사 이름대기 과제를 실시하였을 때, 명사 보다 동사 산출에 더 어려움이 있었다. 그러나 비디오로 동적 자극 을 제시하였을 때에는 정적 자극 제시 조건보다 동사 이름대기 수 행력이 유의하게 높았으며, 명사 이름대기 수행과 유의한 차이가 나타나지 않았다. 알츠하이머형 치매(Dementia of Alzheimer's Type) 환자를 대상으로 한 Fung et al. (2001)의 연구에서도 정적 자 극인 그림보다 동적 자극인 애니메이션 조건에서 대상자들의 동사 이름대기 수행력이 더 높았으며, 명사보다 더 높은 수행력을 보였 다. 반면 뇌혈관 질환(cerebrovascular disease), 종양절제술(begin tumor resection) 등으로 인한 다양한 뇌손상 환자를 대상으로 한 Tranel, Manzel, Asp 그리고 Kemmerer (2008)의 연구에서는 자극 에 따른 동사 산출에 유의한 차이가 없었으며, 오히려 동적 자극인 비디오보다 정적 자극인 사진에서 높은 수행력이 나타났다고 보고
하였다.

한국 실어증 환자를 대상으로 동사 논항구조에 대한 연구는 시 도되어 왔지만, 동사 자극 제시 유형에 관한 연구는 제한적이다. Choi와 Sung (2014)은 정상 노년층을 대상으로 그림과 애니메이션 을 사용하여 자극유형 및 동사 논항구조에 따른 연구를 진행하였 으며, 자극유형에 따라 동사 논항 별 이름대기 수행력의 차이를 나 타냈다고 보고하였다. 이러한 결과는 자극유형이 실어증 환자의 동 사산출에도 영향을 미칠 수 있음을 시사한다.

이에 본 연구에서는 동사 논항구조에 따른 실어증 환자의 동사 산출 능력이 정적 및 동적 자극유형에 따라 어떤 차이를 보이는지 정상 성인과 비교하여 분석하고자 하며, 파라다이스 한국판 웨스 턴 실어증검사 개정판(Paradise Korean version the Western Aphasia Battery Revised, PK-WAB-R; Kim \& Na, 2012)의 실어증 지수 (Aphasia Quotient, AQ)에 따른 실어증 중증도를 예측할 수 있는 논항구조를 자극유형별로 살펴보고자 한다.

\section{연구방법}

\section{연구대상}

본 연구는 서울 및 경기도 소재에 거주하고 있는 실어증 환자 16 명과 정상 성인 16 명을 대상으로 하였다. 본 연구에 참여하는 모든 대상자에게 연구의 목적, 실험내용 및 절차, 소요 시간 등을 안내한

Table 1. Demographic information of participants with aphasia

\begin{tabular}{|c|c|c|c|c|c|c|c|c|c|c|}
\hline \multirow[b]{2}{*}{ No. } & \multirow[b]{2}{*}{ Gender } & \multirow{2}{*}{$\begin{array}{l}\text { Age } \\
\text { (yr) }\end{array}$} & \multirow{2}{*}{$\begin{array}{c}\text { Education } \\
\text { (yr) }\end{array}$} & \multirow{2}{*}{$\begin{array}{l}\text { Post onset } \\
\text { (yr) }\end{array}$} & \multirow[b]{2}{*}{ Type of aphasia } & \multicolumn{5}{|c|}{ PK-WAB-R } \\
\hline & & & & & & $\mathrm{A} 0$ & Fluency & $\begin{array}{l}\text { Comprehen- } \\
\text { sion }\end{array}$ & Repetition & Naming \\
\hline 1 & $\mathrm{~F}$ & 51 & 16 & 2 & Anomic & 91.3 & 9 & 8.45 & 9.8 & 9.4 \\
\hline 2 & M & 61 & 12 & 5 & Conduction & 70.2 & 9 & 6.6 & 3.4 & 8.1 \\
\hline 3 & $\mathrm{~F}$ & 41 & 16 & 1 & Conduction & 72.6 & 8 & 6.8 & 5 & 8.5 \\
\hline 4 & M & 64 & 12 & 5 & Anomic & 76.1 & 6 & 7.65 & 8.8 & 8.6 \\
\hline 5 & M & 60 & 12 & 13 & Anomic & 87.1 & 9 & 9.05 & 7.7 & 8.8 \\
\hline 6 & $M$ & 69 & 6 & 14 & Anomic & 89.8 & 9 & 8.6 & 10 & 8.3 \\
\hline 7 & M & 54 & 16 & 7 & Broca & 68.3 & 3 & 8.85 & 5.6 & 8.7 \\
\hline 8 & $F$ & 63 & 12 & 2 & Anomic & 90.1 & 9 & 8.35 & 9.8 & 8.9 \\
\hline 9 & M & 67 & 12 & 10 & Transcortical motor & 64.1 & 4 & 7.45 & 8.4 & 7.2 \\
\hline 10 & M & 72 & 12 & 5 & Anomic & 90.6 & 9 & 8.6 & 9.6 & 9.1 \\
\hline 11 & M & 45 & 16 & 8 & Anomic & 83.2 & 8 & 8.6 & 8.4 & 8.6 \\
\hline 12 & $\mathrm{~F}$ & 58 & 12 & 9 & Transcortical sensory & 60.1 & 5 & 6.25 & 7.6 & 6.2 \\
\hline 13 & M & 56 & 16 & 2 & Anomic & 85.2 & 8 & 8.9 & 9 & 8.7 \\
\hline 14 & $F$ & 66 & 12 & 12 & Anomic & 86.2 & 6 & 9.6 & 9.4 & 9.1 \\
\hline 15 & M & 31 & 16 & 5 & Broca & 58.8 & 4 & 7.9 & 4 & 7.5 \\
\hline 16 & M & 72 & 16 & 10 & Anomic & 90.5 & 9 & 8.25 & 9.5 & 9.5 \\
\hline
\end{tabular}

PK-WAB-R=Paradise Korean version the Western Aphasia Battery Revised (Kim \& Na, 2012); F=Female; M= Male; AQ=Aphasia Quotient. 
후 서면으로 서명동의를 받았으며, 이화여자대학교 생명윤리위원 회의 승인을 받아 진행하였다(IRB No. ewha-201910-0002-01).

실어증 환자는 (1) 좌뇌 피질 및 피질하 부위의 뇌졸중으로 인해 언어장애를 보이는 자, (2) 파라다이스 한국판 웨스턴 실어증검사 개정판(Paradise Korean version the Western Aphasia Battery Revised, PK-WAB-R; Kim \& Na, 2012) 검사 결과 실어증으로 진단된 자, (3) 발병 이전에 뇌손상 및 기타 신경학적 질환이 없다고 보고된 자, (4) 연령과 교육수준의 차이가 수행에 미치는 영향을 최소화하 기 위해 75세 이하이며 학력이 초등학교 졸업 이상인 자를 대상으 로 선정하였다. 연구에 참여한 실어증 환자의 정보는 Table 1 과 같다.

정상 성인은 (1) 실어증 환자 집단과 평균 연령 및 평균 교육년수가 일치하는 자, (2) 간이정신상태 검사(Korean-Mini Mental State Examination; Kang \& Na, 2003) 실시 결과가 연령 및 교육년수에 비해 $16 \%$ ile 이상으로 정상 범위에 해당하는 자(Kang, 2006), (3) 언어 및 신경학적 손상, 병력이 보고되지 않은 자를 대상자로 선정하였다.

모든 대상자는 원활한 과제 수행을 위해 자가보고를 통해 시력 과 청력에 이상이 없는 자로 선정하였으며, 오른손잡이를 대상으 로 하였다.

집단 간 연령과 교육년수에 통계적으로 차이가 유의한지 알아보 기 위하여 각각 독립표본 $t$-검정을 실시한 결과, 두 집단 간 연령 및 교육년수의 차이가 통계적으로 유의하지 않았다 $(p>.05)$. 두 집단 간 연령 및 교육년수에 대한 평균 및 표준편차는 Table 2에 제시하였다.

\section{실험 자극}

\section{동사 선정}

목표 동사는 1 항 비능격 동사, 1 항 비대격 동사, 2항 동사, 3항 동 사로 구분하였다. 각 논항별 10 개씩 총 40 개의 동사를 선택하였다. 목표 동사는 국내의 성인 실어증, 노년층 등을 대상으로 한 동사산 출 및 중재 관련 연구 중 동사 목록이 제시된 논문 13 편과 『현대 한 국어의 어휘빈도』(Seo, 1998)를 참고하여 선정하였다.

동사의 선정 기준은 (1) 그림으로 표현이 가능한 동사로 선정하였 으며, (2) 인지, 심리 및 감정 동사와 '명사+하다' 형태의 동사를 제외 하였고, (3) 2-3음절 동사이며, (4)『현대 한국어의 어휘 빈도』(Seo, 1998)에 따라 빈도 수 100 이상의 고빈도 동사 및 1,000 이상의 최

Table 2. Participants' age and education

\begin{tabular}{lllc}
\hline Variable & $\mathrm{NC}(\mathrm{N}=16)$ & $\mathrm{PWA}(\mathrm{N}=16)$ & $t$ \\
\hline Age & $58.81(11.53)$ & $58.13(11.51)$ & -.169 \\
Education & $12.88(2.63)$ & $13.38(2.80)$ & .520 \\
\hline
\end{tabular}

Values are presented as mean (SD).

$\mathrm{NC}=$ Normal controls; PWA = Persons with aphasia.
고빈도 동사를 선정하였다.

동사 논항구조에 따라 어휘 빈도수에 차이가 있는지 알아보기 위해 일원분산분석을 실시한 결과, 논항구조 간 어휘 빈도수에 통 계적으로 유의한 차이가 없었다 $\left(F_{(3,27)}=.753, p=.530\right)$. 실험에 사용 한 동사 목록은 Appendix 1에 제시하였다.

\section{자극 제작}

목표 동사의 자극 제작 전 평균연령 27.4세(24-34세)의 청년층 39 명(남자 12명, 여자 27명)에게 목표 동사와 관련된 행위자, 대상, 수 여자를 쓰도록 설문을 실시하였다. 설문에 참여한 대상자들이 응 답한 모든 행위자, 대상, 수여자를 정리하여 동사별로 가장 많이 언 급된 답변을 바탕으로 자극 제작을 기획하여 전문 업체에 의뢰하 였다. 자극의 제작 과정에는 언어병리학과 박사과정에 재학중인 언 어치료사 3 명과 언어병리학과 교수가 참여하여 그림에 대한 논의 를 거쳐 수정 작업을 실시하였다. 모든 자극은 흑백선화 그림으로 제작하였다. 정적 자극은 동적 자극 제작에 사용된 프레임들 중 목 표 동작을 가장 핵심적으로 표현한 것으로 판단되는 프레임을 한 컷 선택하여 사용하였다. 동적 자극은 움직임을 표현하기 위해 9-10개의 프레임으로 이루어진 GIF 파일의 애니메이션을 제작하였 으며, 모든 동사의 동작은 반복적으로 나타나지 않고 한 번만 제시 되도록 제작하였다. 자극 예시는 Appendix 2와 같다.

\section{연구 절차}

연구에 참여한 모든 대상자는 정적 자극으로 제시된 동사 이름 대기 과제와 동적 자극으로 제시된 동사 이름대기 과제를 한 번씩 수행하였다. 자극유형에 따른 순서효과(order effect)를 방지하기 위해 역균형화(counter balancing)하여 과제를 제시하였다. 이에 따라 각 집단 내 절반의 대상자는 정적 자극으로 구성된 과제를 먼 저 실시하였으며, 나머지 대상자는 동적 자극으로 구성된 과제를 먼저 실시하였다. 또한 먼저 실시된 과제가 후속 과제의 단서가 되 어 동사 산출에 미치는 영향을 최소화하기 위하여 두 과제 사이에 30 분의 시간을 두었다. 각 자극유형 별 동사 이름대기 과제에서 단 어는 무작위 배열로 제시되었으며, 같은 논항의 단어가 3 회 이상 연 속되어 제시되지 않도록 하였다. 모든 검사를 마친 후, 순서효과가 나타나지 않았음을 확인하기 위해 각 집단 내 정적 자극이 먼저 제 시된 8 명의 평균과 나중에 제시된 8 명의 평균을 독립표본 $t$-검정을 통해 유의한 차이가 나타났는지 확인하였으며, 동적 자극에 대해 서도 동일한 과정을 실시하였다. 그 결과, 각 집단 내 자극유형 별 제시 순서에 따른 수행력의 유의한 차이가 없었으며 $(p>.05)$ 순서 효과가 나타나지 않았음을 알 수 있다. 
정적 및 동적 자극은 검사자의 노트북 화면을 통해 제시되었으 며, 과제를 시작하기 전 “지금부터 화면에 보이는 그림에서 사람이 나 사물이 무엇을 하고 있는지 말씀해주세요.”라고 지시사항을 말 하고 세 개의 연습 문항을 먼저 실시하여 과제를 숙지시킨 후 본 실 험을 실시하였다.

\section{자료 분석}

대상자의 반응에 따라 정반응한 문항은 1점, 오반응한 문항은 0 점으로 계산하였다. 정반응의 기준은 목표 동사를 산출한 경우, 목 표 동사와 의미관련 반응을 산출한 경우(예: 달리다 $\rightarrow$ 뛰다), 목표 동사를 어간으로 취하는 복합 동사를 산출한 경우(예: 달리다 $\rightarrow$ 달 리고 있네)를 정반응으로 하였다. 그 외의 반응(예: ‘-하다') 및 모른 다고 대답한 경우, 무반응을 보인 경우는 오반응으로 하였다.

동사의 논항에 따른 정반응한 문항의 수를 총 문항 수 10 으로 나 눈 후 100 을 곱하여 정반응률(\%)을 계산하였다.

\section{자료의 통계적 처리}

자료의 통계적 처리는 IBM SPSS Statistics 25.0 프로그램을 사용 하여 통계적 분석을 실시하였다. (1) 집단(실어증 환자 vs. 정상 성인) 간 자극유형(정적 자극 vs. 동적 자극)에 따른 동사 논항(1항 비능 격, 1항 비대격, 2항, 3항) 별 이름대기 과제의 수행력 차이를 보기 위해 삼원혼합 분산분석(three-way mixed ANOVA)을 실시하였 다. (2) 자극유형에 따른 동사 논항 별 이름대기 과제의 수행력과 실 어증 중증도 간 예측변인을 살펴보기 위하여 단계적 회귀분석(stepwise regression analysis)을 실시하였다.

\section{연구결과}

\section{집단 간 자극유형 및 동사 논항구조에 따른 이름대기 정반응률 차이 분석}

자극유형 및 동사 논항구조에 따른 이름대기 정반응률에 집단 간 차이가 있는지 알아보기 위해 삼원혼합 분산분석(three-way mixed ANOVA)을 실시하였다. 정적 자극 및 동적 자극 모두에서 실어증 집단에 비해 정상 집단이 동사 논항에 따른 이름대기 정반 응률이 높은 것으로 나타났다. 자극유형 및 동사 논항구조에 따른 집단 간 이름대기 정반응률에 대한 기술통계 결과는 Table 3 및 Figure 1 과 같다.

실어증 집단과 정상 집단 간 주효과가 통계적으로 유의하였다 $\left(F_{(1,30)}=29.525, p<.001\right)$. 즉 실어증 집단이 정상 집단에 비해 유의

Table 3. Descriptive statistics of verb naming accuracy by group

\begin{tabular}{lll}
\hline Argument structure & $\mathrm{NC}(\mathrm{N}=16)$ & $\mathrm{PWA}(\mathrm{N}=16)$ \\
\hline Static mode & & \\
One-place unergative & $86.25(10.25)$ & $60.00(20.66)$ \\
One-place unaccusative & $86.87(13.53)$ & $56.88(15.80)$ \\
Two-place & $84.38(12.63)$ & $58.13(19.74)$ \\
Three-place & $82.50(14.83)$ & $55.62(23.09)$ \\
Dynamic mode & & \\
One-place unergative & $86.88(8.73)$ & $65.62(15.90)$ \\
One-place unaccusative & $86.25(10.25)$ & $64.37(17.88)$ \\
Two-place & $89.38(8.54)$ & $79.38(19.48)$ \\
Three-place & $88.13(12.76)$ & $58.75(23.91)$ \\
\hline
\end{tabular}

Values are presented as mean (SD).

$\mathrm{NC}=$ Normal controls; $\mathrm{PWA}=$ Persons with aphasia.
NC

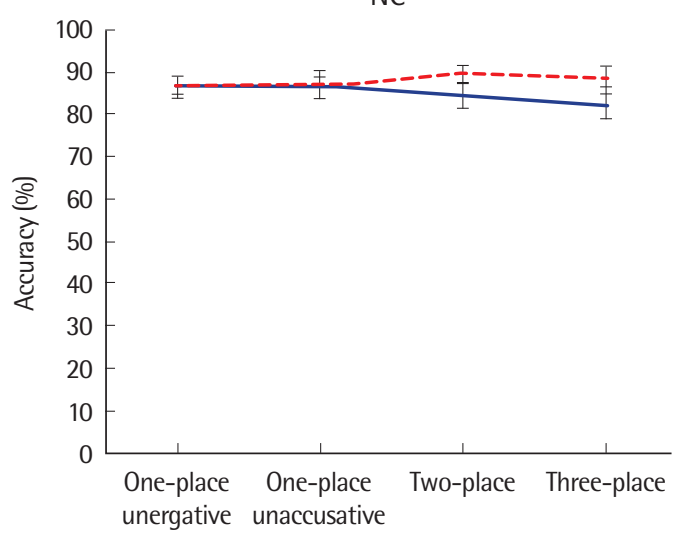

PWA

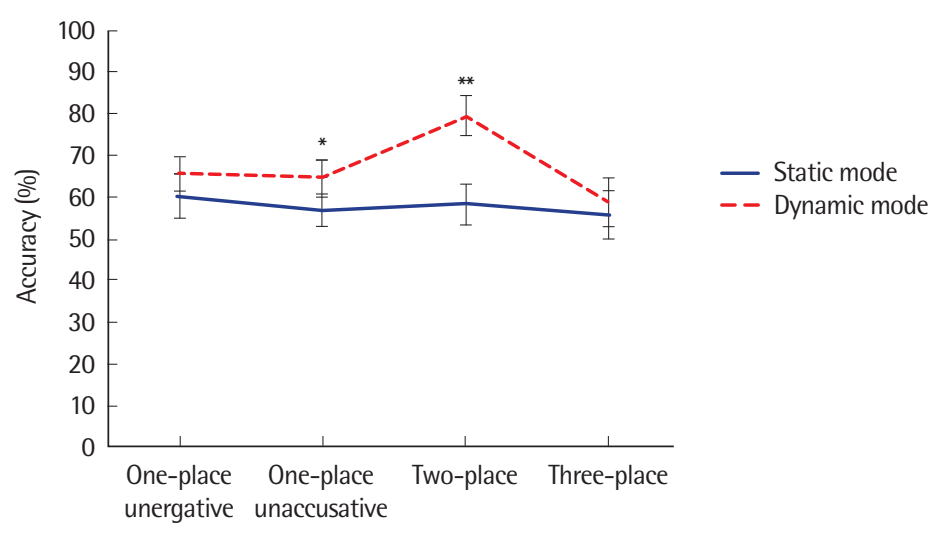

Figure 1. Accuracy on verb production by argument structure and the types of presentation modality for each group. $\mathrm{NC}=$ Normal controls; $\mathrm{PWA}=$ Persons with aphasia . ${ }^{*} p<.05,{ }^{* *} p<.01$. 
하게 낮은 수행력을 보였다. 자극유형에 대한주효과 역시 유의하였 다 $\left(F_{(1,30)}=16.351, p<.001\right)$. 즉 동적 자극일 때 유의하게 높은 수행 력을 나타냈다. 논항에 대한 주효과도 유의하게 나타났으며 $\left(F_{(3,90)}=\right.$ $2.910, p<.05)$, 이에 대한 사후분석으로 Bonferroni를 실시한 결과, 2 항 동사와 3 항 동사간 수행력 차이가 유의하게 나타났다 $(p<.05)$.

자극유형과 집단 간 이차상호작용이 유의하게 나타났다 $\left(F_{(1,30)}=\right.$ $5.099, p<.05)$. 상호작용에 대한 결과는 Figure 2에 제시하였다. 실 어증 집단에서 자극유형 간 차이가 정상 집단에서의 자극유형 간 차이보다 유의하게 큰 것으로 나타났다. 즉 실어증 집단에서 동적 자극을 제시하였을 때 정반응률의 증가가 더 큰 것으로 나타났다.

자극유형과 동사 논항 간 이차상호작용이 유의하게 나타났으며 $\left(F_{(3,90)}=4.854, p<.01\right)$, 결과는 Figure 3 과 같다. 이에 대하여 Syntax 의 MMATRIX 명령문을 사용하여 상호작용 대비검정(interaction contrast)을 사후분석으로 실시하였다. 분석 결과 2 항 동사에서의 자극유형 간 차이가 유의하게 나타났다 $(p<.001)$. 반면 1항 비능격 동사, 1 항 비대격 동사, 3 항 동사에서는 자극유형 간 차이가 유의하 지 않았다. 즉 2 항 동사에서 동적 자극으로 제시하였을 때, 다른 논 항에 비해 수행력 증가가 유의하게 크게 나타났다는 것을 알 수 있 다. 반면 집단과 논항에 대한 이차 상호작용은 유의하지 않았다 $\left(F_{(3,90)}=1.807, p=.152\right)$.

집단 및 자극유형과 논항 간의 삼차상호작용이 유의하게 나타났

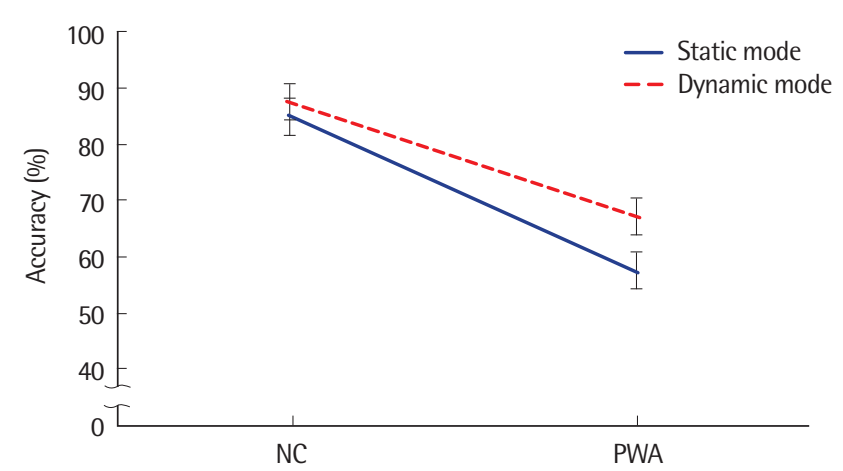

Figure 2. Comparison between static mode and dynamic mode in normal controls (NC) and persons with aphasia (PWA).
다 $\left(F_{(3,90)}=3.215, p<.05\right)$. 삼차상호작용에 대한 결과는 Figure 1 과 같다. 사후검정으로 각 집단별로 자극유형에 따른 동사 논항별 이 름대기 수행의 변화를 살펴보기 위해 반복측정 이원분산분석(twoway repeated ANOVA)를 실시하였다. 그 결과 정상 집단에서는 자 극유형에 따른 동사 논항별 이름대기 수행력의 유의한 차이가 나 타나지 않았다. 반면 실어증 집단에서는 자극유형에 대한 주효과가 유의하게 나타났으며 $\left(F_{(1,15)}=35.526, p<.001\right)$, 정적 자극에 비해 동 적 자극에서 높은 정반응률을 보인 것으로 나타났다. 동사 논항에 대한 주효과 역시 유의하게 나타났으며 $\left(F_{(3,45)}=3.473, p<.05\right)$, 이에 대한 사후분석으로 Bonferroni를 실시한 결과, 2항 동사와 3항 동 사간 유의한차이가 나타났다 $(p<.05)$. 또한자극유형 및 동사 논항 에 대한 이차상호작용이 유의하게 나타났다 $\left(F_{(3,45)}=7.147, p<.01\right)$. 이차상호작용이 유의하게 나타남에 따라 실어증 집단 내에서 각 동사 논항마다 자극유형 간 유의한 차이가 있는지 알아보기 위해 반복측정 일원분산분석(one-way repeated ANOVA)을 실시하였 다. 그 결과 1 항 비대격 동사에서 자극유형 간 유의한 차이가 나타 났다 $\left(F_{(1,15)}=5.00, p<.05\right) .2$ 항 동사 역시 자극유형 간 유의한 차이 가 나타났다 $\left(F_{(1,15)}=68.81, p<.001\right)$. 즉 삼차상호작용은 1 항 비대 격 동사와 2 항 동사에서 자극유형에 따른 수행력 차이가 큰 것으로 나타났으며, 이는 실어증 집단에서만 유의하게 나타난 것에 기인한 것으로 해석된다.

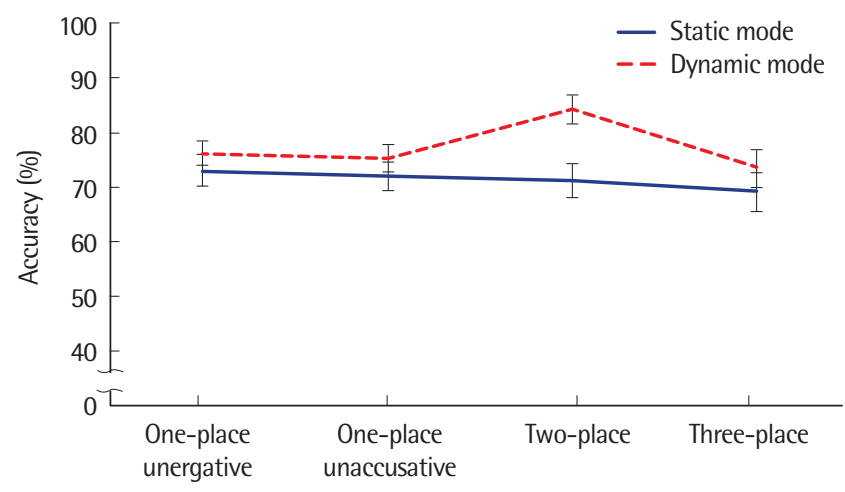

Figure 3. Comparison between static mode and dynamic mode by argument structure.

Table 4. Correlation coefficients among $\mathrm{AQ}$ and verb naming variables on presentation mode and argument structure

\begin{tabular}{|c|c|c|c|c|c|c|c|c|}
\hline & \multicolumn{4}{|c|}{ Static mode } & \multicolumn{4}{|c|}{ Dynamic mode } \\
\hline & $\begin{array}{l}\text { One-place } \\
\text { unergative }\end{array}$ & $\begin{array}{c}\text { One-place } \\
\text { unaccusative }\end{array}$ & Two-place & Three-place & $\begin{array}{l}\text { One-place } \\
\text { unergative }\end{array}$ & $\begin{array}{c}\text { One-place } \\
\text { unaccusative }\end{array}$ & Two-place & Three-place \\
\hline $\mathrm{AO}$ & $.644^{* *}$ & $.614^{*}$ & $.550^{*}$ & $.551^{*}$ & $.745^{* *}$ & $.899 * *$ & $.705^{* *}$ & $.633^{* *}$ \\
\hline
\end{tabular}

$\mathrm{AQ}=$ Aphasia Quotient.

${ }^{*} p<.05,{ }^{* *} p<.01$. 


\section{자극유형 및 동사 논항구조에 따른 이름대기 수행력과 실어증 중증도 간 예측변인 분석}

실어증 중증도와 자극유형에 따른 논항별 이름대기 수행력의 상 관관계를 보기 위해 피어슨 이변량 상관관계(Pearson correlation) 를 실시하였다. 분석 결과, 정적 자극으로 제시하였을 경우 1 항 비 능격 동사 $(r=.644, p<.01), 1$ 항 비대격 동사 $(r=.614, p<.05), 3$ 항 동사 $(r=.551, p<.05), 2$ 항 동사 $(r=.550, p<.05)$ 순으로 유의한 상 관관계가 나타났다. 동적 자극으로 제시하였을 때, 1 항 비대격 동사 $(r=.899, p<.01), 1$ 항 비능격 동사 $(r=.745, p<.01), 2$ 항 동사 $(r=.705$, $p<.01), 3$ 항 동사 $(r=.633, p<.01)$ 순으로 유의한 상관관계가 나타 났다. 상관계수에 대한 결과는 Table 4에 제시하였다.

실어증 집단 내에서 자극유형에 따른 동사 논항구조별 이름대기 변인 중 실어증 중증도를 예측하는 요인을 알아보기 위해 단계적 회귀분석(stepwise regression analysis)을 실시하였다. 실어증 중증 도를 종속변수로, 각 자극유형별 동사 논항별 이름대기 정반응률 을 독립변수로 하여 살펴보았다. 단계적 회귀분석을 통해 다중공 선성을 확인하였으며, Variance Inflation Factor (VIF)가 정적 자 극 조건의 경우 1.156 이었으며, 동적 자극 조건의 경우 1.000 으로 다중공선성이 없는 것으로 판단되었다. 단계적 회귀분석 결과, 정 적 자극으로 제시된 경우 실어증 중증도를 설명해주는 예측변인은 1 항 비능격 동사와 1 항 비대격 동사로 나타났으며 $\left(F_{(2,13)}=8.939\right.$, $\left.p<.01, \mathrm{R}^{2}=.579\right), 57.9 \%$ 예측하는 것으로 나타났다. 동적 자극의 경우 1 항 비대격 동사가 실어증 중증도를 유의하게 예측하는 변인 으로 나타났으며 $\left(F_{(1,14)}=59.215, p<.001, \mathrm{R}^{2}=.809\right), 80.9 \%$ 의 예측 력을 보였다.

\section{논의 및 결론}

본 연구는 실어증 환자를 대상으로 정적 자극과 동적 자극 조건 하에서 동사 논항구조에 따른 이름대기 수행력을 살펴보았으며, 그 결과 실어증 집단은 정상 집단에 비해 동사 산출에 어려움을 나타 내는 것으로 나타났다. 이는 실어증 환자는 어휘 인출의 어려움으 로 인해 이름대기에 어려움을 나타내며(Goodglass \& Wingfield, 1997), 동사 이름대기 과제에서 실어증 환자가 정상 성인에 비해 낮 은 수행력을 나타냈다고 보고한 선행연구의 결과와도 일치한다

(Kim, Park, Kim, \& Hwang, 2004; Sung, 2016; Thompson et al., 1997). 또한 정적 자극을 제시하였을 때의 수행력에 비해 동적 자극 을 제시하였을 때의 수행력이 높은 것으로 나타났으며, 정적 자극 에 비해 동적 자극을 제시하였을 때에 이름대기 수행력이 증가하였 다는 선행연구들과 일치한다(Blankestijn-Wilmsen et al., 2017;
d'Honincthun \& Pillon, 2005, 2008; Fung et al., 2001). 이러한 결 과는 자극유형과 집단 간 상호작용 또한 유의하였으므로 이에 대 한 결과를 아래와 같이 해석해볼 수 있다. 유의한 상호작용의 결과 는 실어증 집단에서 동적 자극으로 제시하였을 때 정상 집단에 비 해 수행력 증가가 크게 나타난 것에 기인하며, 다양한 신경언어장 애 환자를 대상으로 진행한 연구에서 동적 자극을 제시하였을 때 정적 자극보다 더 높은 동사 산출을 보여주었다는 선행연구들과 맥락을 같이 한다(Blankestijn-Wilmsen et al., 2017; d'Honincthun \& Pillon, 2005, 2008). Blankestijn-Wilmsen et al. (2017)은 실어증 환자를 대상으로 한 연구에서 정적 자극과 동적 자극을 제시하여 동사 이름대기 과제를 수행하였을 때, 동적 자극에서 더 높은 수행 력을 나타냈으며 정상 집단에서는 자극에 따른 유의한 차이가 없 었다고 보고하였다. 실어증 환자는 동적 자극으로 제시된 동사 자 극을 볼 때, 운동 및 전운동피질(motor and premotor cortex)의 신 경망(neural network)이 활성화되며 감각운동체계(sensorimotor system)에서의 동사 인출에 영향을 받지만, 정상 집단은 동사 이름 대기의 어려움이 없기 때문에 운동체계의 활성화가 나타나지 않기 때문이다(Blankestijn-Wilmsen et al., 2017). 정상 노년층을 대상으 로 한 Choi와 Sung (2014)의 연구에서는 자극유형에 따라 집단을 나누어 동사 이름대기 수행력을 비교한 결과, 집단 간 주효과가 유 의하지 않은 것으로 나타났다. 즉 정상 집단에게는 자극유형이 동 사 이름대기 수행력을 판단하는 요소로 작용하지 않았기 때문에 전반적인 과제 수행력에 영향을 미치지 않았음을 알 수 있다.

집단과 논항에 대한 이차상호작용은 유의하지 않은 것으로 나타 났다. 상호작용은 통계적으로 유의하지 않았으나, 기술통계 결과를 통해 수행력을 살펴보면 실어증 집단은 2항 동사(68.75\%), 1항 비능 격 동사(62.81\%), 1항 비대격 동사(60.63\%), 3항 동사(57.19\%) 순으 로 높은 정반응률을 보였으며, 정상 집단은 2항 동사(86.88\%), 1 항 비능격(86.56\%) 및 1항 비대격 동사(86.56\%), 3항 동사(85.31\%) 순 으로 높은 정반응률을 보여 두 집단 간 높은 정반응률을 보인 동사 논항의 순서가 동일하였다. 정상 집단의 경우 각 논항 별 정반응률 이 유사하게 나타난 반면, 실어증 집단은 논항에 따른 정반응률에 차이가 있음을 알 수 있다. 동사 논항에 따라 집단 간 정반응률에 차이가 나타났음에도 불구하고 이차상호작용이 유의하게 나타나 지 않은 이유는 제한된 대상자 수에 기인한 것으로 추론된다.

동사 논항에 대한 주효과가 유의하게 나타났다. 2 항 동사, 1 항 비 능격 동사, 1 항 비대격 동사, 3 항 동사 순으로 높은 수행력을 보였으 며, 2항 동사와 3 항 동사에서 유의한 차이가 나타났다. 본 연구의 결 과는 동사 논항이 증가할수록 동사 산출에 어려움을 보인다는 선 행연구들과 부분적으로 일치한다. Sung (2016)과 $\operatorname{Kim}$ (2006)의 연 
구에서도 실어증 환자와 정상 성인 모두 3항 동사에서 가장 낮은 수 행력을 보인 것으로 나타났으나, 1항 및 2항 동사에서는 유의한 차 이가 나타나지 않았다고 보고하였다. 본 연구의 결과 역시 3항 동사 에서 가장 낮은 수행력을 보였으며, 2항 동사와 3 항 동사에서 유의 한 차이가 나타난 점에서 부분적으로 일치한다. 그러나 Kim과 Thompson (2000)은 실어증 환자들이 3항, 2항, 1항 동사 순서로 오 류를 보였으며 3항 동사에서 수행력이 낮았다는 점은 본 연구와 일 치하나, 모든 논항 간 유의한 차이가 있었다고 보고한 점에서 차이 가 있다. 이러한 이유는 영어와 한국어의 언어적 특성 차이에서 기 인한 것으로 해석할 수 있다. 영어는 동사에 따라 주어, 목적어, 보 어 등의 문장 구성 성분이 명확하게 제시되어야 하며, 이 중 하나의 성분이 생략되면 불완전한 문장으로 여겨지는 반면, 한국어는 동 사 외의 성분을 생략하여도 문장이 성립되는 특성이 있어 논항 수 에 따른 구분이 상대적으로 명확하지 않다(Kim, 2006; Yang, 2016). 또한 본 연구에서는 2 항 동사에서 가장 높은 정반응률이 나타난 점에서 선행연구들과 차이가 있으며, 실어증 집단에서 동적 자극 으로 제시한 2 항 동사에서 높은 수행력을 보인 것에서 기인한 것으 로 해석된다. 자극유형에 따른 논항 별 수행력에 유의한 차이가 나 타났다. 1 항 비능격 동사, 1 항 비대격 동사, 3 항 동사에서 자극유형 간 유의한 차이가 나타나지 않았으나, 2항 동사에서는 자극유형 간 차이가 유의하게 나타났기 때문이며, 실어증 집단에서 유의한 수행 력 증가를 보인 것에서 기인한 것으로 해석된다. 이러한 실어증 집단 의 수행력 증가와 관련된 결과는 집단 간 자극유형 및 논항에 대한 삼차상호작용이 유의한 것과 함께 아래와 같이 해석해볼 수 있다.

집단과 자극유형 및 논항에 대한 삼차상호작용이 유의한 것으 로 나타난 것은 정상 집단에서는 자극유형에 따른 동사 논항 별 이 름대기 수행력에 유의한 차이가 없었던 것에 비해, 실어증 집단에 서는 1 항 비대격 동사 및 2 항 동사에서 동적 자극으로 제시하였을 때 정적 자극보다 유의하게 높은 수행력을 보인 것에서 기인한 것이 다. Sung과 Kwag (2012)은 1항 비대격 동사는 무생물이 주어가 되 는 동사로 사물이나 식물과 일치하는 동사가 한정되어 있기 때문 에 정상 성인은 1 항 비대격 동사 산출에 어려움이 없다고 보고하였 다. 하지만 1항 비대격 동사는 대상(theme)이 주어가 되는 복잡성 으로 인해 실어증 환자가 어려움을 보이는 동사이다(Sung, 2016). 그러나 동적 자극으로 1 항 비대격 동사를 제시하였을 때, 동작의 주체가 되는 사물의 움직임이 명확하게 드러나게 되어 정적 자극으 로 제시하였을 때보다 실어증 집단 내에서 수행력이 증가한 것으로 해석된다. Buccino et al. (2001)은 동적 자극으로 동작을 제시하고 관찰하는 동안 전운동영역(premotor cortex)이 활성화되며, 타동 사처럼 동사에 목표 대상(object)이 제시되는 경우 두정엽(parietal lobe)이 활성화된다고 하였다. Ouden, Fix, Parrish 그리고 Thompson (2009)은 정적 자극 조건에서 자동사와 타동사 간 신경활성화 의 유의한 차이가 없었지만, 동적 자극 조건에서 신경활성화의 유 의한 차이가 나타났다고 한다. 동적 자극으로 제시된 타동사를 산 출할 때 우뇌 두정엽의 모서리위이랑(supramarginal gyrus)의 다 중연합영역피질(multimodal association cortex)과 중심후회(postcentral gyrus)의 체성감각영역(somatosensory cortex)에서 강한 활성화가 나타났으며, 두정엽의 이 영역들은 사물조작(object manipulation)과 관련이 있고, 행동의 목표 대상이 제시되는 타동사의 처리(transitive action processing)에 영향을 주는 영역이다(Buccino et al., 2001; Ouden et al., 2009). 이와 같은 특정 영역의 신경활성 화의 차이로 인해 동적 자극이 자동사보다 타동사 산출에 더욱 영 향을 주며, 이름대기에 어려움이 없는 정상 집단에 비해 실어증 집 단에서 타동사 2항 동사 산출 시 자극유형에 따른 영향을 더 받은 것으로 해석된다. 반면 3항 동사의 경우, 논항의 증가에 따라 시각 적 제시가 증가되어 정적 자극에서 목표 동사에 대한 인식이 명확 해져 동적 자극과차이가 나타나지 않은 것으로 추론된다.

자극유형별 동사 논항에 따른 이름대기 변인 중 실어증 중증도 를 가장 잘 설명하는 동사 논항을 살펴본 결과, 정적 자극에서 1 항 비능격 동사와 1 항 비대격 동사가 실어증 중증도를 약 $57.9 \%$ 설명 할 수 있는 것으로 나타났으며, 동적 자극에서는 1항 비대격 동사가 실어증 중증도를 약 $80.9 \%$ 설명할 수 있는 것으로 나타났다. 즉 실 어증 중증도를 잘 예측할 수 있는 동사 과제를 사용하기 위한 동사 논항은 1 항 비능격 동사와 1항 비대격 동사이며, 두 자극유형 모두 에서 1 항 비대격 동사가 실어증 중증도를 예측하는 논항으로 나타 났다. 1항 비대격 동사는 논항이 하나인 동사이지만 대상(theme)이 주어로 이동하면서 어순이 도치되어 피동형(passive structure)과 같이 복잡한 통사구조를 가지고 있는 논항이며(Sung, 2016), 선행 연구를 통해 실어증 환자는 비대격 동사에 어려움을 나타낸다고 밝혀진 바 있다(Kegl, 1995; Kim, 2006; Sung, 2016). 즉 논항 수의 증가에 따른 문장의 길이 증가보다 비대격 동사가 갖고 있는 피동 형태의 통사적 복잡성으로 인한 조작부담(computational load)이 실어증 중증도에 대해 설명력이 높은 것으로 해석된다. 동적 자극 인 애니메이션을 사용한 Sung (2016)의 연구에서도 위와 같은 이유 로 실어증 환자들은 비능격 동사보다 비대격 동사에서 더 낮은 수 행력을 보였음을 알 수 있다. 하지만 능동사인 비능격 동사는 통사 적 복잡성이 낮은 특성이 있으며, 동작의 움직임이 나타나지 않는 정적 자극과 달리 동적 자극의 조건에서는 자극의 움직임이 실어 증 중증도와 상관없이 충분한 단서로 제공되어 예측 변인으로 나 타나지 않은 것으로 해석된다. 
선행연구들에 의하면 유창성 여부에 따른 실어증 환자의 품사별 어휘 인출 결함의 양상이 비일관적인 것으로 보고되었다(Bates et al., 1991; Hyun et al., 2003). 또한 본 연구는 McNeil과 Pratt (2001) 의 실어증 정의를 기준으로 하며, 실어증 유형 및 손상 부위에 따른 특정 언어손상의 기준을 정의하는 것에 한계가 있다는 의견에 따라 유창성 여부에 따른 수행력을 비교하지 않았다. 하지만 실어증이 가 변성(variability)을 특징으로 한다는 점을 고려할 때(McNeil \& Pratt, 2001) 환자의 개별적 양상을 파악하는 것은 중요할 수 있다. 향후 연구에서는 실어증 환자의 개별 특징을 파악하고 이러한 개인 차가 자극유형에 따른 동사 산출에 어떤 영향을 줄 수 있을지에 대 한 연구가 필요할 것으로 보인다. 또한 동사 논항을 연구한 선행연구 에 사용된 지시문을 살펴보면, 본 논문과 같이 사람이나 사물이 무 엇을 하고 있는지' 질문하며 행위자를 지칭하여 지시하거나(Sung $\& \mathrm{Kwag}, 2012)$, '무엇을 하고 있는지', '어떻게 되었는지'와 같이 행위 자를 지칭하지 않았지만 격조사를 사용하여 질문하였다(Kim, 2006; Yang, 2016). 지시문을 통해 대상자의 목표 반응을 이끌어내 는 것은 명사 이름대기 과제에 비해 동사 이름대기 과제에서 대상자 의 어휘 인출에 더욱 영향을 미칠 수 있다. 따라서 동사 산출 및 문 장 처리와 관련된 과제는 검사자의 지시문에 사용된 격조사에 따른 점화 효과를 연구하여 지시문의 통일성을 구축할 필요가 있다.

본 연구결과를 통해 실어증 환자는 자극유형의 제시 방법에 따 라 동사 논항에 따른 이름대기 수행력을 다르게 나타내는 것을 확 인할 수 있었다. 향후 임상에서 대상자 평가 시 자극유형과 동사 논 항을 고려할 필요가 있으며, 목표 동사에 따라 적절한 자극유형을 선택하여 중재에 적용하여 대상자의 반응을 유도할 수 있음을 시 사한다. 실어증 중증도를 예측하는 변인으로 정적 및 동적 자극 모 두 1 항 비대격 동사가 포함되어 있었다. 이러한 결과는 동사 논항의 증가에 따른 문장길이의 증가보다는 비대격 동사의 특징인 피동 형 태의 구문처리가 실어증 환자의 동사 산출 능력과 관련이 있음을 시사한다.

\section{REFERENCES}

Bates, E., Chen, S., Tzeng, O., Li, P., \& Opie, M. (1991). The noun-verb problem in Chinese aphasia. Brain and Language, 41(2), 203-233.

Berndt, R. S., Mitchum, C. C., Haendiges, A. N., \& Sandson, J. (1997). Verb retrieval in aphasia. 1. characterizing single word impairments. Brain and Language, 56(1), 68-106.

Bird, H., Howard, D., \& Franklin, S. (2003). Verbs and nouns: the importance of being imageable. Journal of Neurolinguistics, 16(2-3), 113-149.
Blankestijn-Wilmsen, J., Damen, I., Voorbraak-Timmerman, V., Hurkmans, J., de Koning, J. B., Pross, A., \& Jonkers, R. (2017). The effect of static versus dynamic depictions of actions in verb and sentence production in aphasia. Aphasiology, 31(10), 1166-1182.

Buccino, G., Binkofski, F., Fink, G. R., Fadiga, L., Fogassi, L., Gallese, V., Seitz, R. J., Zilles, K., Rizzolatti, G., \& Freund, H. J. (2001). Action observation activates premotor and parietal areas in a somatotopic manner: an fMRI study. European Journal of Neuroscience, 13(2), 400-404.

Choi, S. J., \& Sung, J. E. (2014). Task-specific and argument structure effects on verb production in normal elderly adults: animation vs. picture comparisons. Journal of Rehabilitation Research, 18(4), 279-293.

De Bleser, R., \& Kauschke, C. (2003). Acquisition and loss of nouns and verbs: parallel or divergent patterns? Journal of Neurolinguistics, 16(2), 213-229.

d'Honincthun, P., \& Pillon, A. (2005). Why verbs could be more demanding of executive resources than nouns: insight from a case study of a fv-FTD patient. Brain and Language, 95(1), 36-37.

d'Honincthun, P., \& Pillon, A. (2008). Verb comprehension and naming in frontotemporal degeneration: the role of the static depiction of actions. Cortex, 44(7), 834-847.

Dorze, G., \& Nespoulous, J. L. (1989). Anomia in moderate aphasia: problem in accessing the lexical representation. Brain and Language, 37(3), 381-400.

Druks, J. (2002). Verbs and nouns - a review of the literature. Journal of Neurolinguistics, 15(3-5), 289-315.

Druks, J., \& Shallice, T. (2000). Selective preservation of naming from description and the "restricted preverbal message". Brain and Language, 72(2), 100128.

Fung, T., Chertkow, H., Murtha, S., Whatmough, C., Péloquin, L., Whitehead, V., \& Templeman, F. (2001). The spectrum of category effects in object and action knowledge in dementia of the Alzheimer's type. Neuropsychology, 15(3), 371-379.

Goodglass, H., \& Wingfield, A. (1997). Word-finding deficits in aphasia: brainbehavior relations and clinical symptomatology. In H. Goodglass \& A. Wingfield (Eds.), Anomia: neuroanatomical and cognitive correlates (pp. 3-27). New York: Academic Press.

Hillis, A. E., \& Caramazza, A. (1991). Category-specific naming and comprehension impairment: a double dissociation. Brain, 114(5), 2081-2094.

Hyun, J. M., Kim, H. H., Shin, J. C., \& Seo, S. G. (2003). Retrieval of nouns and verbs in Broca's and Wernicke's aphasia. Korean Journal of Communication \& Disorders, 8(3), 171-187.

Jonkers, R., \& Bastiaanse, R. (1996). The influence of instrumentality and 
transitivity on action naming in Broca's and anomic aphasia. Brain and Language, 55(1), 37-39.

Jonkers, R., \& Bastiaanse, R. (1998). How selective are selective word class deficits? two case studies of action and object naming. Aphasiology, 12(3), 245-256.

Kang, Y. W. (2006). A normative study of the Korean-Mini Mental State Examination (K-MMSE) in the elderly. The Korean Journal of Psychology: General, 25(2), 1-12.

Kang, Y. W., \& Na, D. L (2003). Seoul Neuropsychological Screening Battery (SNSB). Seoul: Human Brain Research \& Consulting.

Kegl, J. (1995). Levels of representation and units of access relevant to agrammatism. Brain and Language, 50, 151-200.

Kemmerer, D., \& Tranel, D. (2000). Verb retrieval in brain-damaged subjects: 1. analysis of stimulus, lexical, and conceptual factors. Brain and Language, 73(3), 347-392.

Kim, H. H., \& Na, D. L. (2012). Paradise Korean version the Western Aphasia Battery Revised (PK-WAB-R). Seoul: Paradise Welfare Foundation.

Kim, K. Y. (2006). Verb Production and argument structures in aphasics (Master's thesis). Yonsei University, Seoul, Korea.

Kim, M., \& Thompson, C. K. (2000). Patterns of comprehension and production of nouns and verbs in agrammatism: implications for lexical organization. Brain and language, 74(1), 1-25.

Kim, S. R., Park, C. I., Kim, D. Y., \& Hwang, M. A. (2004). Production of nouns and verbs in adults with broca’s aphasia: comparison between naming and narration. Korean Journal of Communication \& Disorders, 9(2), 1-18.

Luzzatti, C., Raggi, R., Zonca, G., Pistarini, C., Contradi, A., \& Pinna, G. D. (2002). Verb-noun double dissociation in aphasic lexical impairments: the role of word frequency and imageability. Brain and Language, 81(1-3), 432-444.

Mätzig, S., Druks, J., Masterson, J., \& Vigliocco, G. (2009). Noun and verb differences in picture naming: past studies and new evidence. Cortex, 45(6), 738-758.

McNeil, M. R., \& Pratt, S. R. (2001). Defining aphasiaa: some theoretical and clinical implications of operating from a formal definition. Aphasiology,
15(10/11), 901-911.

Nam, S. H. (2007). Event structure and argument structure of Korean predicates. Seoul National University Press.

Ouden, D. B., Fix, S., Parrish, T. B., \& Thompson, C. K. (2009). Argument structure effects in action verb naming in static and dynamic conditions. Journal of Neurolinguistics, 22(2), 196-215.

Pashek, G. V., \& Tompkins, C. A. (2002). Context and word class influences on lexical retrieval in aphasia. Aphasiology, 16(3), 261-286.

Raymer, A. M., Kohen, F. P., \& Saffell, D. (2006). Computerised training for impairments of word comprehension and retrieval in aphasia. Aphasiology, 20(02-04), 257-268.

Seo, S. (1998). Word frequency in modern Korean language. Seoul: Language and Information Development Center, Yonsei University.

Sung, J. E., \& Kwag, E. J. (2012). Age-related verb naming abilities depending on the argument structures. Korean Journal of Communication \& Disorders, 17(4), 550-564.

Sung, J. E. (2016). The effects of verb argument complexity on verb production in persons with aphasia: evidence from a subject-object-verb Language. Journal of Psycholinguistic Research, 45(2), 287-305.

Thompson, C. K., Lange, K. L., Schneider, S. L., \& Shapiro, L. P. (1997). Agrammatic and non-brain-damaged subjects' verb and verb argument structure production. Aphasiology, 11(4-5), 473-490.

Thompson, C. K. (2003). Unaccusative verb production in agrammatic aphasia: the argument structure complexity hypothesis. Journal of Neurolinguistics, 16(2), 151-167.

Tranel, D., Manzel, K., Asp, E., \& Kemmerer, D. (2008). Naming dynamic and static actions: neuropsychological evidence. Journal of Physiology - Paris, 102(1-3), 80-94.

Yang, Y. M. (2016). Study on the relationship between verb processing and argument structure in patients with Broca's aphasia (Master's thesis). Daegu University, Gyeongbuk, Korea.

Zingeser, L. B., \& Berndt, R. S. (1990). Retrieval of nouns and verbs in agrammatism and anomia. Brain and Language, 39(1), 14-32. 
Appendix 1. 동사 목록

\begin{tabular}{ccccl}
\hline No. & 1항 비능격 동사 & 1항 비대격 동사 & 2항 동사 & 3항 동사 \\
\hline 1 & 걷다 & 깨지다 & 누르다 & 꺼내다 \\
2 & 구르다 & 끓다 & 밀다 & 꽃다 \\
3 & 기다 & 녹다 & 신다 & 던지다 \\
4 & 날다 & 내리다 & 열다 & 따르다 \\
5 & 달리다 & 마르다 & 입다 & 떼다 \\
6 & 돌다 & 시들다 & 접다 & 바르다 \\
7 & 울다 & 썩다 & 줍다 & 박다 \\
8 & 웃다 & 자라다 & 찢다 & 뽑다 \\
9 & 자다 & 타다 & 짜다 & 심다 \\
10 & 짖다 & 피다 & 차다 & 주다 \\
\hline
\end{tabular}

Appendix 2. 정적 및 동적 자극 예시

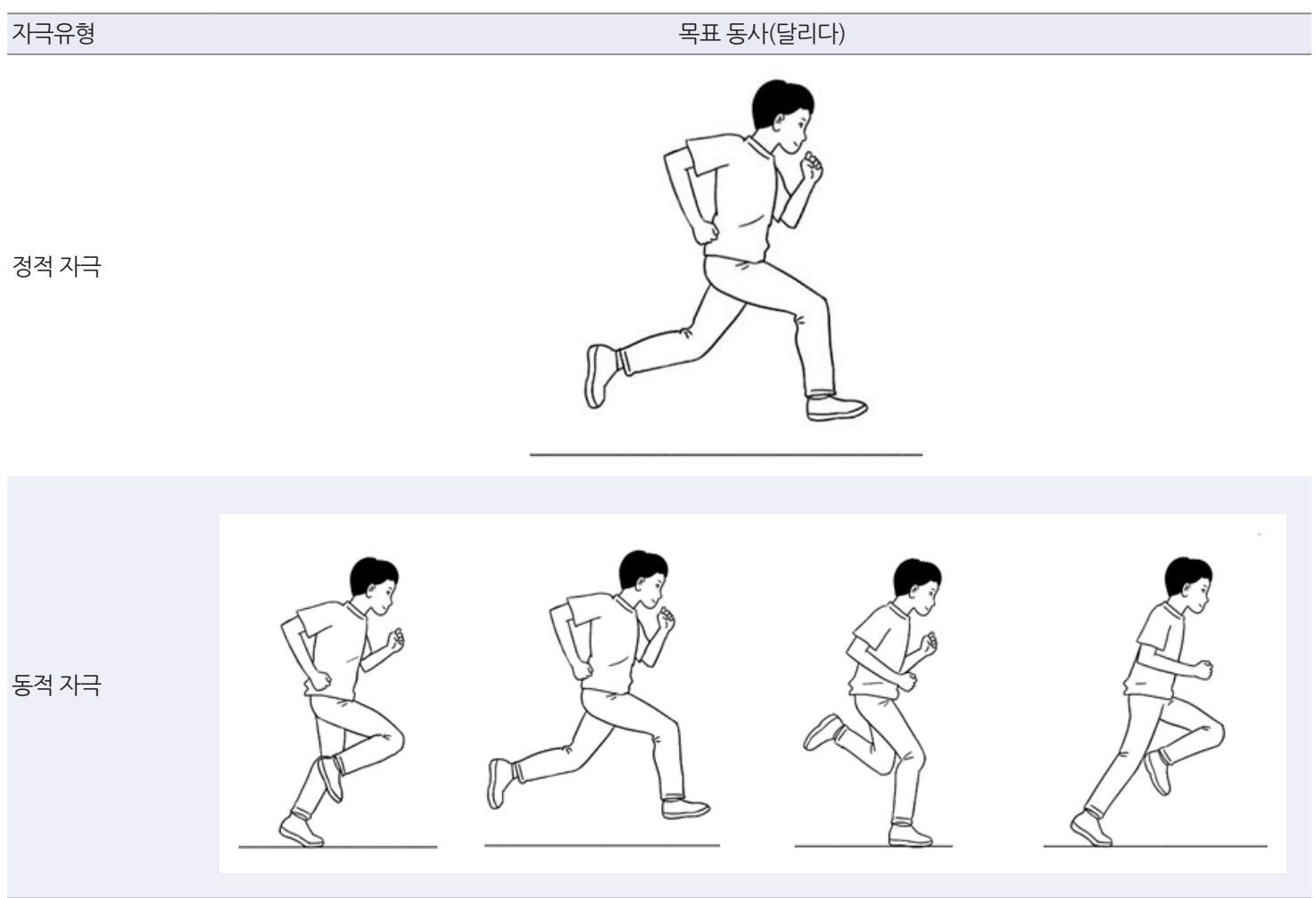




\section{국문초록}

\section{자극 제시 유형 및 동사 논항구조에 따른 실어증 환자의 동사 이름대기 특징}

\section{윤혜수 · 성지은}

이화여자대학교 언어병리학과

배경 및 목적: 본 연구에서는 실어증 환자와 정상 성인을 대상으로 정적 및 동적 자극유형으로 제시된 동사 논항구조에 따른 이름대기 수행능력을 비교하고자 하였으며, 실어증 환자 집단 내에서 자극유형별 이름대기 변인 중 실어증 중증도를 예측하는 변인을 알아보고 자 하였다. 방법: 실어증 환자 16 명과 정상 성인 16 명을 대상으로 하였으며, 각 논항별 10 개씩 총 40 개의 목표 동사를 선정하였다. 모든 대상자는 정적 자극과 동적 자극으로 이루어진 동사 이름대기 과제를 실시하였으며, 자극유형에 따른 제시 순서는 역균형화(counterbalancing)하여 제시하였다. 결과: 실어증 집단이 정상 집단에 비해 자극유형에 따른 동사 논항별 이름대기 정반응률이 유의하게 낮았 다. 정상 집단은 자극유형에 따라 동사 논항별 이름대기 수행력에 차이가 없었지만, 실어증 집단은 동적 자극으로 제시하였을 때 1 항 비 대격과 2 항 동사에서 수행력이 증가하였다. 실어증 중증도를 예측하는 변인은 정적 자극으로 제시된 1 항 비능격 및 1 항 비대격 동사와 동적자극으로 제시된 1항 비대격 동사로 나타났다. 논의 및 결론: 실어증 환자는 뇌손상으로 인해 동사 산출에 어려움을 보였으나, 제 시되는 자극유형에 따라 수행력 증가가 나타났다. 문장 내 대상(theme)이 주어로 이동하며 어순 도치로 인해 피동구조가 되는 통사적 복잡성을 가진 1 항 비대격 동사의 조작부담이 실어증 중증도에 대해 설명력이 높은 변인이다.

핵심어: 실어증, 동사 논항구조, 자극유형, 애니메이션

본 연구는 2017년도 대한민국 교육부와한국연구재단의 지원을 받아 수행된 연구임(NRF-2017S1A2A2038375).

\section{참고문헌}

강연욱, 나덕렬(2003). 서울신경심리검사(Seoul Neuropsychological Screening Battery, SNSB). 서울: 휴브알엔씨. 강연욱(2006). K-MMSE (Korean version of Mini-Mental State Exam)의 노인 규준 연구. 한국심리학회지: 일반, 25(2), 1-12.

김가영(2006). 실어증 환자의 동사산출과 논항구조 간의 관계. 연세대학교 대학원 석사학위논문.

김수련, 박창일, 김덕용, 황민아(2004). 브로카 실어증 환자의 과제간 명사와 동사의 산출 비교. 언어청각장애연구, 19(2), 1-18.

김향희, 나덕렬(2001). 파라다이스- 한국판-웨스턴 실어증검사. 서울: 파라다이스 복지재단.

남승호(2007). 한국어 술어의 사건 구조와 논항 구조. 서울대학교출판부.

서상규(1998). 현대 한국어의 어휘 빈도. 연세대학교 언어정보개발연구원.

성지은, 곽은정(2012). 연령 및 동사 논항 구조에 따른 애니메이션을 활용한 동사 이름대기 과제 수행력 차이. 언어청각장애연구, 17(4), 550-564. 양유미(2016). 브로카실어증 환자의 동사처리와 논항구조간의 관계. 대구대학교 대학원 석사학위논문.

최수진, 성지은(2014). 과제 제시 유형 및 논항 수에 따른 노년층의 동사 이름대기 수행력 차이: 애니메이션과 그림 비교. 재활복지, 18(4), 279-293.

현정문, 김향희, 신지철, 서상규(2003). 베르니케실어증과 브로카실어증 환자들의 명사와 동사 인출비교. 언어청각장애연구, 8(3), 171-187.

\section{ORCID}

윤혜수(제1저자, 대학원생 https://orcid.org/0000-0002-7497-687X); 성지은(교신저자, 교수 https://orcid.org/0000-0002-1734-0058) 